\title{
03 CURBING VIOLENCE IN EMERGING MARKET COMMUNITIES IN DELTA STATE NIGERIA
}

doi:10.1136/injuryprev-2012-040590j.3

${ }^{1} \mathrm{M}$ Ajufo, ${ }^{2} \mathrm{E}$ Ekwuoba, ${ }^{3} \mathrm{C}$ Ojugbana, ${ }^{4} \mathrm{~A}$ Magbor. ${ }^{1}$ PATVORA Initiative NGO 013,

Asaba, Delta state, Nigeria; ${ }^{2}$ PATVORA Initiative NGO 014, Asaba, Delta state, Nigeria; ${ }^{3}$ PATVORA Initiative NGO 001, Asaba, Delta state, Nigeria; ${ }^{4}$ PATVORA Initiative NGO 010, Asaba, Delta state, Nigeria

Background Emerging market communities in Nigeria bring with it influx of people and increased commercial activities to the existing community. Studies conducted on such communities have always indicated that such increase in population also come with some criminal activities like stealing, drug peddling, prostitution and other unlawful activities.

Aims/Objectives/Purpose To curb violence and criminal in emerging market communities.

Methods A 3 months study was conducted in three emerging markets in Asaba (Afia -Hausa market), Okwe (Iyanga market) and Oko (Cattle market) all in Delta State, Nigeria. Direct interviews and observations were carried out.

Results/Outcomes Results showed existence of commercial sex centres and drug peddling activities, all the 60 officials of the market union interviewed agreed that criminal activities existed. $93 \%$ of the 100 Members of the communities interviewed agreed that activities had increased by about $200-300 \%$ in the communities. No police presence or drug enforcement agency presence was recorded.

Significance/Contribution to the Field An effective community vigilante service is necessary to be established in these new emerging market communities comprising of members from the old and new inhabitants. Narcotic control and police authorities should conduct regular visits and surveillance in these new communities. Crime report centres should be established. These recommended steps when implemented would assist in curbing violence and crime in these communities. 